\title{
Trafficking of women in Entikong Sub-District Sanggau Regency, Indonesia
}

\author{
Mukhlis \\ Faculty of Social and Political Sciences, Universitas Tanjungpura, Indonesia
}

Correspondence author email: mukhlisfisipuntan@gmail.com

\begin{tabular}{|l|l|l|l|l|}
\hline DOI: & Received: & Revised: & Accepted: & Published: \\
10.22437/ppd.v9i2.13079 & 30.06 .2020 & 20.03 .2021 & 23.06 .2021 & 30.06 .2021 \\
\hline
\end{tabular}

\begin{abstract}
This study investigates and analyzes various phenomena related to transnational trafficking of women in Entikong Sub-District, Sanggau Regency, West Kalimantan, from the recruitment of the departure abroad to various human rights violations experienced by Indonesian women. The qualitative analysis method is used in this study. In general, trafficking of women in the Indonesia-Malaysia border regions is a phenomenon that arises due to the lack of legal protection, both while the victims are still in Indonesia and after they arrive abroad. This phenomenon has a negative impact on ensuring legal protection for women and the impact on the emergence of human rights violations (torture, harassment, exploitation, intimidation, rape, confinement, and forced sexual intercourse.).
\end{abstract}

Keywords: Exploitation, Migrant workers, Trafficking of women

JEL Classification: I30, K42, Z13

\section{INTRODUCTION}

Various international trafficking of women cases under the pretense of recruiting Indonesian female migrant workers (Tenaga Kerja Wanita/TKW) occurs primarily in areas directly bordering neighboring countries. It also happened in Entikong SubDistrict, Sanggau Regency, West Kalimantan Province, which is near Malaysia. According to the data from LSM Anak Bangsa Sanggau (2008), the number of women who became victims of trafficking through the Entikong Cross-Border Post (PLB Entikong) in 2005, 2006, 2007, and 2008 respectively were 103 cases, 545 cases, 414 cases, and 102 cases. The majority of the trafficking victims worked in nightclubs for their Malaysian employers (hereinafter addressed as tauke). They were compelled to entertain clients/customers, and if they refused, they would be punished, tortured, confined without being fed, threatened, and subjected to other human rights violations.

The rising number of trafficking cases, both directly and indirectly, has aggravated the impoverishment of Indonesian women, and law violation has become more common. Weak enforcement of laws encourages the proliferation of fraudulent practices, bribery, and document manipulation. It enables corruption and bribery to be extremely common, particularly in settlement of trafficking cases out of court. It is difficult to obtain accurate and reliable data on trafficking woman victims in Entikong District. However, several women from this region have recently returned from Sarawak (Malaysia) and have shared their unpleasant experiences of being scammed by the traffickers posing as labor brokers. 
Based on the explanation above, this study aims to describe the process of transnational trafficking of women in the Indonesia-Malaysia border area under the pretense of sending female workers abroad by the labor brokers, to examine the factors enabling transnational trafficking of women, and to determine the preventive measures for the trafficking cases.

\section{LITERATURE REVIEW}

Trafficking of women is intertwined with economic, social, cultural, political, and legal issues on a national and global level. Individuals/women who are the victims are not the only ones who suffer; families and communities are often affected. The victim is subjected to exploitation and violence, which is a dishonor to the family. Furthermore, there will be a rise in prostitution and immoral acts and an impact on poverty and powerlessness in the community.

According to Soesilo (1994, 20), trafficking is defined as activities committed to hand women over to other parties for prostitution, including those who usually look for young women to be sent abroad and become prostitutes/sex workers. United Nations (UN) defines human trafficking as the recruitment, transportation, transfer, harboring or receipt of people through force, fraud or deception, abuse of power, or the giving and receiving payment to obtain permission from a person who has authority over another person, with the aim of exploiting them for profit (Komisi Nasional Perempuan, 2000). Furthermore, the Global Alliance Against Traffic in Women (GAATW) (2019) emphasizes three key elements in the concept of women trafficking: recruitment, transit, and cross-border.

In human trafficking, women are generally treated as products that may be purchased and consumed by others. This fact aligns with Dellyana's (1998, 118) argument that women in modern society are used for trade purposes. Soewondo (1984, 307) also argues that women in the productive sector tend to be regarded as commodities with a market value. Murray (1995) explains that the perception of women as commodities is influenced, among other things, by the weak value system in the family, which stems from individualistic and materialistic socioeconomic conditions. However, women in prostitution do not only work for financial gain. Women are often forced and coerced into prostitution by men in various ways, including false promises of job opportunities, marriage or enslavement disguised as love, forming loyalty to pimps, and physical kidnapping and confinement (Truong, 1992, 18).

According to Hull et al. (1997, 99), prostitution is induced by women's lack of education. Non-economic reasons, such as the high divorce rates, particularly among Javanese families, also pushed young women to become sex workers. Meanwhile, according to Sikwan $(2004,12)$, poor education and poverty are factors pushing the migration of Indonesian women of Chinese descent (called amoi) to Taiwan/Hong Kong. The poor socioeconomic conditions of the amoi families required female family members to work, yet their low level of education limited their career possibilities. Women are frequently subjected to unjust treatment due to their restricted career opportunities, such as being tricked into becoming sex objects in the trafficking.

Based on the different perspectives presented above, it is clear that the reasons leading to trafficking result from a chain of social, economic, and cultural elements. In general, socio-cultural issues, which are strongly connected to institutionalized social construction and unbalanced gender roles, are the most significant obstacles in eliminating the cycle of women trafficking.

In the trafficking of women, women are at the bottom of the cycle. They experience violence committed by clients in illegal sexual activities. Physical impairments, STDs, HIV/AIDS, and unexpected pregnancies are all risks to these 
women's reproductive health. Therefore, laws to protect women from human trafficking, particularly criminal laws, are critical. Kanter and Sianturi $(1982,55)$ state that the purpose of criminal law is to protect the interests of individuals or human rights and the interests of society and the state from immoral conduct on the one hand and arbitrary authority action on the other hand.

Article 296, 297, and 506 of the Penal Code of Indonesia (KUHP) prohibit women from being trafficked, but its implementation has not fully guaranteed the protection of women's rights, particularly the rights of freedom and sexual \& reproductive health \& rights (SRHR). It is because the existing laws are not gendersensitive and are no longer relevant to contemporary situations. According to Syaifuddin (1996, 40), gender-sensitive policies represent the interests of men and women equally. Local governments must play a more active role, particularly in developing gender-sensitive policies for the prevention or elimination of trafficking, and this is in line with the opinion of Nuh $(2005,13)$, which states that local governments must cooperate with other institutions, such as NGOs and other institutions, to carry out those three activities: prevention, protection, and prosecution.

\section{METHODS}

The subjects of this study are all women from Entikong District, Sanggau Regency who returned from Malaysia and had become victims of trafficking as informants. Determination of informants was carried out by purposive sampling. In addition, the author also met key informants: Entikong Class II Immigration office personnel, Entikong Village Head office personnel, LSM Anak Bangsa (Anak Bangsa NGO), Entikong police officers, and the labor brokers(also worked as traffickers). After gathering data/information from informants and key informants, the research problems were assessed according to the actual situation in the field.

This study used data collection techniques, namely: 1) In-depth interviews; 2) Non-participant observation; and 3) Documentation studies.

According to Miles and Huberman $(1992,20)$, the qualitative analysis method consists of four activities: gathering information, field notes, presenting information, and drawing conclusions. Clarification, interpretation, and data analysis are all part of the analysis process and are carried out simultaneously. Clarification and data classification is carried out in parallel with the data collection process in the field. Data analysis is done descriptively and includes qualitative interpretation, which is followed by discussion and analysis. In this paper, numerous phenomena linked to the transnational trafficking of women carried out by labor brokers are discussed and analyzed.

\section{RESULTS AND DISCUSSION}

\section{Factors that contribute to trafficking of women}

Local situations encouraged the practice of trafficking via PLB Entikong to Malaysia. Several factors contributed to this practice based on field observations, including economic factors, education factors, cultural factors, and consent factors.

\section{Economic factors}

In general, women in Entikong Sub-District who were victims of human trafficking are relatively young (15-19 years old) and come from five villages (Entikong, Semangit, Nekan, Pala Pasong, Suruh Tembawang) and other villages near Entikong Sub-District. The victim's parents are from a poor household living as farmers, agricultural laborers, casual laborers, and fishers with uncertain monthly incomes.

The trafficking of women is an open secret in Entikong District. Based on interviews with informants, trafficked women generally come from poor households 
with 5-6 dependent household members. In order to help their family, female family members were eager to work abroad as illegal migrant workers (not registered in the Regional Office of Manpower and Transmigration Department [Depnakertrans]). Consequently, when a labor broker offered them jobs abroad, they rarely turned down the offer.

Poverty has been identified as one of the primary reasons for the trafficking of women, particularly young people. Dalimoenthe (2018) found that economic considerations are one of the reasons for women becoming victims of human trafficking in DKI Jakarta, where the victims came from poor households with uncertain earnings. Furthermore, the difficulties of finding work in the village pushed women to leave their homes and traveled to larger cities, where they ended up working as commercial sex workers. Lack of money is also the main reason for East Nusa Tenggara women to leave their homes and end up becoming victims of human trafficking (Kiling \& Kiling-Bunga, 2019).

The migration of village women from Entikong District to another country was done in groups and coordinated directly by a trafficker. The trafficker usually went to the victim's house as a labor recruitment bureau officer persuaded the victim's parents to agree and send their daughter to work as a female migrant worker. Meanwhile, their daughters had little option but to comply with their parents' demands, even if they had no prior knowledge of working abroad. The trafficker would lie or give false promises of high salaries, guaranteed living facilities, low workloads, and excellent employers. In addition, as a token of appreciation, they would also give money to the victim's parents. Sutinah and Karen (2019) discovered similar findings, in which the traffickers persuaded the victims' families to allow their daughters to work abroad by approaching the parents in a friendly manner.

The trafficking of women under the pretense of recruiting female migrant workers is a well-organized syndicate network that is difficult to break and involves a number of parties, including law enforcement personnel. This is why human trafficking through PLB Entikong is common and does not appear suspicious because women can work overseas through official routes with passports. In Central Java, Astuti (2008) discovered the involvement of security forces and the court as well as immigration authorities in facilitating the existence of modern trafficking. However, in his research on Madurese women working in Saudi Arabia and Malaysia, Dzulkarnain (2015) discovered different facts about the legality of the departure of the victims. The majority of Madurese women who worked and became trafficking victims in these two countries went as illegal workers.

\section{Education factors}

Most trafficked women in Entikong Sub-District have a junior high school diploma and below, and some have not even graduated from elementary school. Because of their lack of formal education, women in Entikong Sub-District were easily deceived by traffickers posing as labor brokers. Furthermore, victims were unfamiliar with labor regulations and procedures for working abroad, so cooperating with labor brokers in processing the required documents was their only option. Unfortunately, they were forced to do different work, which was not the same as the promised job. The findings of this study are in line with research from Dzulkarnain (2015), which concludes that a low level of education is one of the push factors for Madurese women to work in Saudi Arabia and Malaysia.

\section{Cultural factors}

In the cultural life of the village community, parents' attitudes about sons and daughters differ significantly. Boys are seen as having a higher economic value than girls. Sons are considered as the family's support system in addition to being the heirs. 
Parents prefer to live with their son despite the son's poor economic condition. When parents live with their sons as breadwinners, they feel respected and more valued.

On the other hand, parents feel shameful if they live with their daughter, even though she is financially sufficient. This finding is following the belief that grown and married daughters belong to someone else. When parents live with their married daughter, they assume that someone else, not their child, provides them. This viewpoint holds even if their daughter is the one who works. Therefore, it is not surprising that parents in the rural Entikong District find it simpler to marry off their daughters and are more willing to provide better education for their sons. They believe that raising girls is a financial strain on the family since girls are perceived to be more consumptive than boys. Thus, parents demand their daughters to marry or work as soon as possible to support the household.

The discriminatory perspective of the parents is one of the factors contributing to the growing practice of transnational trafficking of women in the Entikong Sub-District, both directly and indirectly. Parents had significant economic and cultural reasons for agreeing to have their daughters work abroad, even though it might harm their daughters. Not only in Entikong Sub-District, Sutinah and Karen (2019) discovered this patriarchal cultural factor in East Java, which supported the extensive trafficking of women in the region.

\section{Consent factors}

Trafficking of women via PLB Entikong was done covertly by labor brokers, with little or no permission from the trafficked women. Even though these women agreed to work as migrant workers, they had no idea that they would be trafficked. The approval to work abroad from the victims was also inseparable from the consent of parents who were struggling to make ends meet. This factor also caused the transnational trafficking of women under the pretense of recruiting female migrant workers to be difficult to eradicate.

Trafficked women were frequently in a difficult position to refuse or voice their disapproval. Parents no longer considered their daughters' opinions due to their poor financial situation. Instead, they immediately accepted offers from a labor broker, hoping that their financial situation would improve soon. In addition, when labor brokers sought the victim's parents' approval, they generally gave them money as a token of appreciation. This hospitality led parents to trust the broker and forget about their daughter's worst-case scenario while she is overseas. The victim and the labor broker then travel to Malaysia to meet the tauke as soon as the broker gets approval from the victim's parents.

Non-economic factors had a significant influence in getting consent from the family, in addition to economic factors. Labor brokers encouraged the parents that girls working abroad would have a better life than those who worked in the village. Stories about the successes of Indonesian migrant workers in Malaysia and contributed to household welfare had been one of the motivators for parents to consent to their daughters' departure to Malaysia. The success stories of the migrants as a driver of women to work outside their home were also found in Kiling and Kiling-Bunga's research (2019) in East Nusa Tenggara.

\section{Types of trafficking of women in Entikong}

The number of foreign visitors to Indonesia via PLB Entikong has increased since the President of the Republic of Indonesia issued Decree Number 15 of 1991 concerning the Policy for Tourism Development in Indonesia, allowing foreigners to visit Indonesia for three months without requiring a visa. It was also felt in West Kalimantan in general and in Sanggau City, particularly with the influx of Malaysians. 
Government policy (Presidential Decree No 15 of 1991) requires every foreign national who enters Indonesia to report to the local immigration office. However, based on information gathered on the fields, many foreigners, particularly those from East Malaysia (including tauke), did not report themselves. The Sanggau Immigration Office claimed that no foreigner from East Malaysia had reported to the immigration office. Therefore, the immigration authorities lacked detailed information on the foreigners' arrival.

Based on most informants' testimony, the arrival of Malaysian tauke, who never reported to the local immigration, was made possible by the cooperation between Malaysian tauke and labor broker in Entikong. The broker would pick up the Malaysian tauke in a private car and drove tauke to the inn upon the arrival at PLB Entikong. Another way to conduct trafficking is that tauke arrived in Entikong or Sanggau by private car and proceeded directly to the broker's residence, ensuring that the arrival of these tauke was extremely neat and seldom created suspicion.

Based on the information obtained in the field, there are several patterns of transnational trafficking of women carried out by labor brokers via PLB Entikong, including:

1. First pattern: The Malaysian employer/tauke travels to Indonesia personally through PLB Entikong to negotiate with an Indonesian labor broker (or trafficker). Usually, the labor broker brings women who will be sent to Malaysia. Apart from the fee that the labor broker will receive for the number of women they can bring to Malaysia, they generally talk about types of jobs and salaries for the recruited women;

2. Second pattern: The Malaysian tauke does not travel to Indonesia directly but instead dispatches trusted subordinates to meet with an Indonesian labor broker. Negotiations will take place at a time and location determined by the broker;

3. Third pattern: The Malaysian tauke does not travel to Indonesia and does not dispatch his subordinate. Negotiations are carried out by phone. If the two parties reach an agreement, the tauke will go to Indonesia, or the labor broker/trafficker will travel to Malaysia, providing photographs of the women he has recruited to the tauke. The recruited women will then be transported to Malaysia by the broker.

4. Fourth pattern: The labor broker takes the recruited women to PLB Entikong immediately after getting permission from the women's parents. The labor broker persuades and tells the parents that their daughter will get employed in Malaysian companies. Upon arriving in Malaysia, however, the women will be handed over to the previously-contacted tauke or a Malaysian tauke through another trafficker in Malaysia.

The first and fourth patterns of trafficking are the most common pattern carried out by the traffickers in Indonesia. All informants who were victims of trafficking in Entikong said that the labor broker who brought them to Malaysia deceived them. The fraud occurred when brokers came to the victims' houses and made falses promises so that they were willing to work in Malaysia as migrant workers. The victims only realized that they had been scammed after they had arrived in Malaysia.

The victims of trafficking further explained that they would stay at an inn/hotel chosen by the labor broker in Malaysia. Then, the labor broker would contact the Malaysia tauke who would hire them. After the broker and the tauke reached an agreement, women would be handed over to the tauke as the employer. Their Malaysian employer would also keep the victims' passports. After receiving payment from the tauke, the labor broker would return to Indonesia and left the victims at the tauke's residence. Victims were usually shocked after being told by the Malaysian tauke's bodyguards that they would be employed in nightclubs and forced to serve clients. 
Even though the trafficked women were aware of the situation, they were often helpless to refuse the job. Apart from having their passports withheld by their employers, they would be harassed, locked up, intimidated, and subjected to numerous acts of violence by bodyguards if they refuse to work.

\section{The impacts of trafficking of women on victims}

\section{Positive impacts}

Some trafficking victims in Entikong believed that their departure to Malaysia as illegal migrant workers positively impacted their lives, both economically, socially, and psychologically.

In the context of economic impact, women's earnings as illegal migrant workers were higher than their earnings working in Indonesia. They could help their families/parents alleviate financial burdens, repair their homes, and pay for their younger siblings to attend school, all of which enhanced the quality of education for family members directly or indirectly. As a result, it enhanced the family's dignity in society.

In the context of social impact, their departure could provide them with more experience, knowledge, and skills during their stay in Malaysia. All of this might then be turned into an interesting story to tell their family, relatives, and neighbors in Indonesia. During their stay in Malaysia, these women expanded their network as they met and exchanged experiences with many people, both from Indonesia and from other countries.

In the psychological aspect, the women got peace of mind and conviction that they would have a more secure future once they went back to Indonesia, especially when they had savings for setting up a business. These women were also more selfreliant and prouder of themselves to help their economically poor households.

\section{Negative impacts}

Although there are positive impacts for the victims of trafficking, there are also numerous negative impacts. The majority of the victims are no longer willing to go to Malaysia due to their difficult and unpleasant life experiences. Based on the information obtained in the field, many victims experienced mistreatment such as being insulted, beaten, tormented, held hostage, intimidated, and other forms of abuse that go beyond the boundaries of humanity. If they refused to serve customers in the nightclub, they would be treated harshly. Meanwhile, the victims who were compelled to serve customers are commonly infected with STDs, unplanned pregnancies, and some are even suspected of contracting HIV/AIDS, all of which are detrimental to their reproductive health.

As a result of the unpleasant experiences, many of the victims suffered extreme psychological stress, including depression and prolonged trauma when recalling their life in Malaysia. During the research, many victims refused to become informants because they were ashamed and scared of men who came to their houses.

The victims usually returned to Indonesia by fleeing their workplace and reporting the crime to the Consulate General of the Republic of Indonesia in Kuching. They would, after that, be repatriated to Indonesia. On the other hand, some of the victims discreetly got their passports back from the employer/tauke's room and left after asking other people or neighbors for help to return to Indonesia.

When numerous cases involving women from Entikong Sub-District and nearby villages were studied further, it becomes clear that the victims had no legal protection. Until recently, the victim's case has been treated as a completely private concern rather than a public concern, and these victims have not received adequate legal protection. 


\section{Law enforcement response to trafficking of women}

\section{Socio-juridical aspects in trafficking cases}

In Entikong Sub-District and nearby villages, a societal culture favors boys and restricts girls' access to primary and secondary education. As a result, the number of women with an insufficient level of education is relatively high. In addition to being favored, boys are also seen to have a higher economic value than girls, resulting in gender discrimination against women in Entikong Sub-District. Religious practices and government policies that do not entirely protect women's rights also contribute to this discrimination.

In general, trafficking of women occurs in societies with weak law enforcement and bureaucracies, and it can be seen from various socio-juridical aspects related to the trafficking of women that is largely unaddressed by law. Several cases related to sociojuridical aspects in Entikong Sub-District and nearby villages were found, including Indonesian residential identity card (KTP) and passports forgery, fraud by offering jobs in companies/restaurants, and acts of violence suffered by victims of trafficking.

\section{Forgery of trafficked woman's identity}

In Entikong Sub-District, the age of the victim was frequently falsified. Falsifying the age was meant to allow victims who were still underage to get KTP as the first step to applying for other official state documents. The fragility of bureaucracies allowed human trafficking to happen. Furthermore, certain parties had benefited from this illegal activity regarding document issuances. Government officials usually did not carefully check the documents of migrant worker candidates, especially if the documents were to find a job. By bribing the officials, documents would be processed fast.

Based on the observations in the field, age falsification opened the door to other bureaucratic violations, particularly in passport issuance. Officials in charge, such as village heads, subdistrict heads (camat), and immigration officers, would generally refer to the completeness of the paperwork rather than verifying the accuracy of the information on the documents. Thus, the scams in document issuance continue.

\section{Fraud against trafficked woman}

In addition to falsifying the victims' identity, brokers frequently deceived victims, mainly regarding the types of work offered. The majority of the victims were offered jobs in Malaysia as shop clerks, enterprise workers, or waitresses. However, they were compelled to work at nightclubs, and the victims had no power to refuse. This can be categorized as an act of fraud.

\section{Violence experienced by woman}

Victims were subjected to psychological, physical, and sexual assault in addition to fraud. The victim was subjected to psychological abuse in the form of pressure from parents to work and false promises from the labor broker, leaving the victim with little option but to accept the offer as migrant workers. Meanwhile, victims were frequently subjected to physical assault in the destination country. Almost all informants (victims) stated that they had been subjected to physical abuse by their employer's bodyguards in Malaysia, including slapping, hair grabbing, kicking, and other harsh treatments. Even though acts of violence in trafficking are serious crimes, these crimes have never been subjected to the same legal consequences as other serious crimes. This can be proven by the fact that almost none of the traffickers is prosecuted legally.

Victims of torture and sexual abuse suffer from the same physical injuries as victims of domestic violence, and in some cases, they are much more severe and require hospitalization. In general, victims of the abuse are suffering from various psychological traumas, including nightmares, difficulties concentrating, anger management issues, feeling humiliated, and a tendency to blame themselves. 


\section{Obstacles in handling cases of trafficking}

Although the trafficking of women case is highly complicated and rooted in an unequal pattern of gender relations, the Entikong Police Department appeared to be unconcerned about it. As a result, no case is ever entirely resolved, and victims often felt disappointed with the police. Based on the interviews with the informants, the police investigated and asked numerous personal and private matters when the victim reported the fraud and abuse. Labor brokers who had deceived victims, on the other hand, remained unpunished.

According to the victims' testimonies, several reasons prevented them from reporting acts of fraud and violence to the police, including: 1) The testimonies of victims of violence in the trafficking of women were merely heard without any followup by the police to take legal action against the perpetrator; 2) There is no priority in handling the case of violence in the trafficking of women; 3) The tendency of the police to be suspicious of the victim's report, even suspecting the victim as the perpetrator; 4) The tendency of the police to resolve the case by amicable settlement between victim and perpetrator, or sending victim home and advising the victim not to file a formal report.

On the other hand, based on the interviews with Entikong Police personnel (key informants), the police believed that they had attempted to deal with various acts of violence against women. However, those cases were not due to trafficking, and the outcomes were not as expected. Due to the difficulty of proving the truth, the violence in human trafficking cases has not been handled well by the authorities. Furthermore, almost all of the victims did not report their cases to the police. According to the police, case complaints were often related to labor agreement issues, which were more likely to be civil cases. Furthermore, the Entikong Police Department stated that the efforts to resolve human trafficking cases were not optimal due to several obstacles, including: 1) The number of Entikong Police officers is limited, and they have poor performance; 2) Communication and operational assistance are insufficient, so the police cannot cover cases in the areas prone to women trafficking.

Based on the interviews with the trafficking victims and police officers, it can be concluded that dealing with human trafficking cases is challenging due to various obstacles, both from with the police apparatus and from the victims.

\section{Model law against the trafficking of women}

In Indonesia, [KUHP], in particular articles 296, 297, and 506, provide legal protection and rights to be free from arbitrary acts for women victims of human trafficking (BPHN, 1985: 120).

Article 296 of the Indonesia Penal Code stated: "Any person who makes an occupation or a habit of intentionally causing or facilitating any obscene act by others with third parties, shall be punished by a maximum imprisonment of one year and four months or a maximum fine of one thousand rupiahs."

Article 297 of the Indonesia Penal Code stated: "Trade in women and minors of the male sex shall be punished by a maximum imprisonment of six years."

Article 506 of Indonesia Penal Code stated: "Any person who as souteneur takes advantage of the prostitution of a roman, shall be punished by a maximum light imprisonment of one year."

The trafficking of women in the Entikong Sub-District under the pretense of recruiting female migrant workers is not covered in the articles above. This demonstrates the weakness and backwardness of Indonesia's criminal law system in responding to the emergence of new forms of crime in Indonesia. As several of the victims pointed out, the trafficking of women cases was frequently seen as a criminal case. Employment fraud is simply defined as breaking promises, and the violence 
against the victim case is a civil case since it is connected to the employment contract with the employer.

The articles mentioned above of the Indonesian Penal Code are also unable to protect women who were employed as prostitutes in foreign countries, and law enforcement officials in Malaysia usually had trouble arresting criminals. The labor brokers in Entikong often claimed that they did not involve in trafficking and only brought the victim to a Malaysian tauke since the victim chose to work there.

The case of violence against trafficking victims is one that frequently goes unnoticed. The majority of these cases were not reported immediately by the victims and their families for the four reasons indicated before. In addition, an informant revealed that she and her family received threats from certain individuals if she reported the case to the police. One of the informants reportedly said that the officers blamed her when she sought legal protection from the police.

Many women in Entikong District continued to be victims of human trafficking due to gender discrimination in many opportunities, including education, employment, and gaining legal protection. At the same time, the government's policies of limiting safe and legal methods of sending migrant workers, namely that candidates, who will be sent, need to possess skills, will only further limit women's rights and make human trafficking more entrenched and rooted in people's lives.

Based on the results of field observations and learning from experience about the ineffectiveness of law enforcement in taking action against traffickers in the Entikong Sub-District, strategies in handling the trafficking of women cases were created to eliminate this illegal practice, including: 1) Active engagement from all levels of society in the combat against human trafficking, especially trafficking of women; 2) Encouragement of law enforcement officers or women to the community or NGOs to report people suspected of being traffickers, and; 3) Strict legal action against officials participating in or supporting the human trafficking practice.

\section{CONCLUSIONS AND RECOMMENDATIONS}

\section{Conclusions}

The dominant push factors in trafficking in Entikong Sub-District are poverty, low levels of woman's education, patriarchal cultural values in society (girls' value is lower than boys'), and parents' pressure for their daughters to work abroad without considering the daughters' opinions.

The forms of transnational trafficking in Entikong Sub-District are: 1) Malaysian employer/tauke travels to Indonesia via PLB Entikong to have negotiations with the trafficker posing as labor broker; 2) The Malaysian tauke sends his subordinate to meet the labor broker in Indonesia to negotiate; 3) The Malaysian tauke negotiates with Entikong broker by phone; and 4) Broker brings recruited women to Malaysia via PLB Entikong. The broker approaches the victim's parents to send their daughter for a highpaying job in Malaysia.

Trafficking of women has both positive and negative impacts on victims. The positive impacts felt by the victims are higher income, helps to relieve the family's financial burden and pays for their younger siblings to attend school, and enhancing the family's socioeconomic status in the community. Additionally, victims also got more insight, knowledge, connections, and life experience by staying abroad. On the other hand, victims felt adverse effects such as being treated inhumanely, contracting STDs, having unwanted pregnancies, and contracting HIV/AIDS.

Because the Entikong Police have entirely resolved the human trafficking cases, the trafficking does not appear to be taken as a serious crime. The obstacles encountered 
in handling these cases are difficulties in proving the truth and the unwillingness of victims to report their cases to the police.

\section{Recommendations}

Local governments and law enforcement officers must immediately bring order and take strict action against the traffickers, both individuals and legal entities, who engage in the transnational trafficking of women while posing as a labor broker for female workers. It is illegal to take women from Entikong District and nearby villages to work in foreign countries by giving them false promises of high-paying employment.

It is necessary to immediately establish cooperation between the local governments, relevant agencies, and official labor recruiting companies (PJTKIs) in Sanggau in order to provide accurate and timely information to women and their families about the procedures to follow, various risks of working abroad, legal protection provided to them as migrant workers, as well as the risks of being illegal migrant workers. With sufficient information, it is possible to prevent women from becoming illegal migrant workers, therefore breaking the chain or eliminating the practice of human trafficking.

The subdistrict heads (camat) and village heads should be granted the authority to arrange the necessary paperwork for individuals who would travel overseas as migrant workers. It is aimed to avoid the falsification of age during the registration for KTP and family registers (KK).

It is essential to enforce immigration procedures that are in line with applicable laws. It is necessary to prevent violations by the traffickers posing as officers in labor recruiting companies and impose strict punishments on the traffickers.

The Sanggau Government and related officials must immediately provide counseling to the community, particularly village women, and explain that working abroad (Malaysia) through labor brokers is a form of human trafficking that often includes fraud, violence, intimidation, coercion to become prostitutes, and other forms of violence against women. The governments also have to encourage the community to carefully consider efforts to eradicate the trafficking of women in all of its forms.

The Government must immediately enact gender-sensitive legislation that specifically regulates the prohibition of trafficking of women. The legislation must prevent and break the chain of trafficking and protect the rights of trafficking victims. In addition, all parties must be able to be bound by newly enacted rules and regulations. It means that they must take firm action against any perpetrators (indiscriminately), including those directly or indirectly involved in human trafficking. Furthermore, it is necessary to have control by the community; in this case, the role of NGOs must be empowered to control and monitor the implementation of laws and regulations related to human trafficking in Indonesia.

\section{REFERENCES}

Astuti, T.M.P. (2008). Antropologis tentang trafficking TKW di Malaysia: Antara ada dan tiada. Forum Ilmu Sosial, 35(2), 113-123.

Badan Pembinaan Hukum Nasional (BPHN). (1985). Kitab Undang-Undang Hukum Pidana. Jakarta: Sinar Harapan.

Dalimoenthe, Ikhlasiah. (2018). Pemetaan jaringan sosial dan motif korban human trafficking pada perempuan pekerja seks komersial. Jurnal Pendidikan Ilmu-Ilmu Sosial, 10(1), 91-103.

Dellyana, S. (1988). Wanita dan anak dimata hukum. Yogyakarta: Liberty.

Dzulkarnain, I. (2015). Perempuan korban perdagangan manusia di Madura. KARSA: Journal Sosial Budaya dan KeIslaman, 23(1), 36-56. 
Global Alliance Against Traffic in Women [GAATW]. (1997). Practical guide to assisting trafficked women. Bangkok: GAATW

Hull, T. H., Sulistyaningsih E., \& Jones G.W. (1997). Pelacuran di Indonesia: Sejarah dan perkembangannya. Jakarta: Pustaka Sinar Harapan.

Kanter, E.Y., \& Sianturi, S.R. (1982). Asas-asas hukum pidana di Indonesia dan penerapannya. Jakarta: Alumni AHM-PTHM.

Kiling, I.Y., \& Kiling-Bunga, B. N. (2019). Motif, dampak psikologis, dan dukungan pada korban perdagangan manusia di Nusa Tenggara Timur. Jurnal Psikologi Ulayat, 6(1), 83-101.

Komisi Nasional Perempuan. (2000). Perdagangan perempuan, migrasi perempuan dan kekerasan terhadap perempuan: Penyebab dan akibatnya. Seri Dokumen Kunci. Jakarta: Publikasi Komnas Perempuan.

Miles, B. M., \& Huberman, A. M. (1992). Analisis data kualitatif. Jakarta: UI Press.

Murray, A. J. Pedagang jalanan dan pelacur Jakarta: Sebuah kajian antropologi sosial. Jakarta: LP3ES.

Nuh, M. (2005). Jejaring anti trafficking: Strategi penghapusan perdagangan perempuan dan anak. Yogyakarta: PSKK UGM.

Ritzer, G. (2002). Sosiologi ilmu pengetahuan berparadigma ganda. Jakarta: PT. Raja Grafindo Persada.

Saptari, R., \& Brigitte H. (1997). Perempuan, kerja, dan perubahan sosial. Jakarta: Grafiti.

Sikwan, A. (2004). Tragedi perdagangan amoi Singkawang. Yogyakarta: PSKK UGM.

Soesilo. R. (1994). Kitab Undang-Undang Hukum Pidana (KUHP) serta komentarKomentarnya. Bogor: Politica.

Soewondo, N. (1984). Kedudukan wanita Indonesia dalam hukum dan masyarakat. Jakarta: Ghalia Indonesia.

Sutinah, S., \& Karen, M. K. (2019). Trafficking of Women and Children in East Java, Indonesia. Journal of International Women's Studies, 20(9), 94-106.

Syaifudin, H. (1996). Sensitivitas gender dalam perumusan kebijakan publik. Jurnal Analisis Sosial, 4, 37-38 (4): 37-48.

Tamtiari, W. (1998). Dampak sosial perdagangan wanita asal Lombok Timur dengan kedok sebagai migrasi Tenaga Kerja Wanita ke Malaysia. Jurnal Populasi, 10(2), 39-56.

Tim Pusat Studi Wanita (PSW) Untan. (2003). Perdagangan wanita di Kalimantan Barat (Studi kasus terhadap wanita WNI keturunan Cina di Kabupaten Sambas. Pontianak: PSW Untan.

Triantoro, B. W. (1998). Migrasi ilegal ke Malaysia Barat: Kasus perdagangan wanita internasional di Pulau Lombok, NTB. Jurnal Populasi, 10(2), 3-16.

Truong, T-D. (1992). Seks, uang dan kekuasaan, pariwisata dan pelacuran di Asia Tenggara. Jakarta: LP3ES.

(C) 2021 by the authors. Licensee JPPD, Indonesia. This article is an open-access article distributed under the terms and conditions of the Creative Commons Attribution (CC BY) license (http://creativecommons.org/licenses/by/4.0/). 